\title{
Nadell, Pamela S. America's Jewish Women: A History from Colonial Times to Today. New York: W. W. Norton \& Company, 2019.
}

\section{Reviewed by Eric A. Deutsch, University at Buffalo, NY, USA.}

Dr. Pamela Nadell's academic career and specialization may be traced considering her first published monograph, Conservative Judaism in America (1988) $\mathrm{i}$, and volumes she edited including Women and American Judaism (2001) ${ }^{\mathrm{ii}}$ and American Jewish Women's History (2003). ${ }^{\mathrm{iii}}$ Despite appearing at first glance to perhaps consider on well-trodden material, Nadell's most recent work, America's Jewish Women: A History from Colonial Times to Today, finds the Women's and Gender History Chair and Director of the Jewish Studies Program at American University's best. The temporal scope of America's Jewish Women is captured literally in the subtitle - but the title is arguably misleading in terms of the geographic breadth of Nadell's work. Jewish American women, Nadell makes clear from word one, did not appear in the United States organically. Over three centuries, Jewish women left the diaspora for the United States, the result of push factors ranging from pogroms to following a family's patriarch for the promise of a newand better-commercial market.

The subtext of Nadell's thoroughly engaging and approachable monograph is that there is not one exemplar Jewish American woman. Emma Goldman, Emma Lazarus, Emma Wolf, Emma Mordecai - four women Nadell considered - represented the opportunities and limits facing Jewish women in the United States over the centuries of the nation's existence.

America's Jewish Women utilizes a trove of sources ranging from New York's Yiddish turn of the twentieth century periodicals to official reports to diaries of those women considered at a widely varying range of depth.

Nadell's introduction notes the visible and tangible change in American Jewish women from their identity in previous centuries to the present day. Her illustrations of American Jewish women reflects American Jewish women's Americanism - what Nadell considers in depth reflective of trends in coerced and deliberate Americanization and acculturation—but Nadell's introductory references to American Jewish women is used as an entry point through which the author asks what historical and cultural trends have shaped this population and manifested in a diverse group of Americans who at their core remain a singular bloc, despite their growing 
differences in politics and religious practices and beliefs. "American Jewish Women" had a different meaning, Nadell stresses early in her work, throughout the history of the United States.

The five chapters in America's Jewish Women are ordered chronologically, and are typically in conversation with the preceding or subsequent material. Nadell's writing makes for a work that covers three centuries of American history, and explores the varied experiences of Jewish American women existing at particular times and in particular contexts, but a singular narrative emerges that reinforces Jewish American women's shared and distinct identities and experiences.

Nadell's methodology includes consideration of inventories of objects owned by Jewish American women, and the utilization of these sources is most powerfully present in this chapter. Nadell's work traces Jewish American women's roles in the domestic and social spaces, themselves altering dramatically with the times. Before the eighteenth century, Jewish American women, Nadell emphasizes, worked at home while their "overwhelmingly merchants" husbands worked in the public space (16). From the household, Jewish women during this time-for the most part (there was never, it is clear, a time during which Jewish American women represented a unified population) --maintained kosher households. Still, Nadell makes certain to note, the first generations of Jewish American women did frequently leave their household to engage in social life in spaces where their participation was considered essential, including hospitals and schools. Nadell also traces the origins of the Reform movement in the United States, beginning in the midnineteenth century. The author also notes Jewish American women's role in reflecting and influencing social discourse, particularly through publishing periodicals, including The American Jewess, first published in 1895, for other Jewish American women and writing politicallyinfluenced poetry (61).

Nadell analyzes the discourse of Jewish American women concerning issues ranging from suffrage to birth control to Zionism, particularly from the first wave of eastern-European Jewish immigrants in the late nineteenth century through the 1980s. Central to Zionism's consideration in American Jewish life was Hadassah, which organized as a group of likeminded Zionist Jewish American women, but grew to represent and have members of various classes and political beliefs (100-101, 188). Established in 1912, Hadassah, Nadell notes, grew from 27,000 members in 1926 to more than 250,000 members in the years immediately following the Second World War. 
Nadell traces American Jewish women's role in advancing the feminist movementsincluding Betty Friedan, author of The Feminine Mystique, to Bella Abzug, a feminist Jewish Congresswoman from 1971-1977 (236-239).

The book's occasional regrettable words and omissions are notable in an overwhelmingly outstanding work that serves to empower both generations prior and the current generation of Jewish American women. For example, Nadell considers a Yiddish Socialist Newspaper's Bintel Brief (a 'gossip column' in The Forward) which was not, Nadell notes, written solely for the newspaper's female readership, but, Nadell regrettably notes (in a work otherwise focusing on how Jewish American women were not submissive to gendered roles through United States history) that "Female readers were surely drawn to [The Forward's] advice column (135). Nadell notes that The Forward had a column specifically for women readers, so the author's gendered assertions of what otherwise Progressive Jewish women would have been attracted to read is regressive, at best. That Nadell considers Margaret Sanger, who altered the discourse surrounding birth control to one in which birth control "became an expression of Jewish women's politics" is wholly laudable. However, Nadell's absence of considering Sanger's widely-published and well-known championing eugenics is conspicuously absent from America's Jewish Women, and particularly so in a book that, at its core, is about a population subject to genocidal campaigns, many of which resulted in Jewish families fleeing their home countries for the United States.

The book's very title challenges - and provides thoughtful consideration for (and is thus worth reading by) - any person who has ever questioned whether they consider themselves American Jews or Jewish Americans. What does the choice of a modifier or order of an adjective and noun tell us about our identity? Certainly not everything — but Nadell's book historicizes why these existential and questions of self-identification were and remain important. Like the two Jewish American woman whom Nadell notes in her prologue - Grace Mendes Seixas Nathan (1752-1831) and her great-granddaughter Emma Lazarus (1849-1887), the meaning of "Jewish American women" changes immensely over time, and with it the considerations of and discourse surrounding individuals who, despite being of different generations, exemplify the Jewish American woman experience that, despite its dynamism, is timeless: American Jewish women "are simultaneously a part" of the American society in which they live "and yet stand apart from them[,] living in the shadow of the nation's liberties" (7). 
America's Jewish Women is a book worth reading for anyone interested in tracking the eponymous population's role within and in shaping the United States from its founding until present. Professional academics and casual readers interested in the development of Judaism in America and the altering roles of Jewish American women will be greatly rewarded by Nadell's accessible work.

i Pamela S. Nadell, Conservative Judaism in America: A Biographical Dictionary and Sourcebook. (Westport, Connecticut: Greenwood Press, 1988).

ii Pamela S. Nadell and Jonathan D. Sarna, eds., Women and American Judaism: Historical Perspectives (Hanover, New Hampshire: University Press of New England, 2001).

iii Pamela S. Nadell, ed., American Jewish Women's History: A Reader (New York: New York University Press, 2003). 